\title{
MODELLING THE EXTENT OF SUSTAINABILITY OF TOURISM DESTINATIONS IN SERBIA
}

DOI: https://doi.org/10.18509/GBP210137p

UDC: $338.48-44: 332.146 .2(497.1)$

\author{
Biljana Petrevska ${ }^{1}$ \\ Aleksandra Terzić ${ }^{2}$ \\ Cvetko Andreeski ${ }^{3}$ \\ ${ }^{1}$ Faculty of Tourism and Business Logistics, Goce Delčev University, Štip, North Macedonia \\ ${ }^{2}$ Geographical Institute Jovan Cvijić, SASA, Belgrade, Serbia \\ ${ }^{3}$ Faculty of Tourism and Hospitality - Ohrid, St. Clement Ohridski University - Bitola, \\ North Macedonia
}

\begin{abstract}
There are different aspects of perceptions of tourism sustainability. Yet, studies are limited in putting the focus on policy enablers' perception. In this line, the policymakers represent those who contribute to manage and control tourism destination development. The aim of the paper is to identify the level of sustainability of tourism destinations in Serbia from a policy perspective (such as governmental bodies, contributors to management strategies, tourist organizations, etc.). By identifying the main tourism impacts from the three-pillar sustainability dimension, the research determines destinations' operating sustainability. Based on a multi-staged methodology, data was collected by using a qualitative method (expert's judgment and content analysis of the existing strategic tourism development documents) and a quantitative method (219 halfstructured deep interviews). A model is proposed that posts directions for systematic organization of policymakers to infer conclusions on the current state of well-being of tourism destinations. Such model enables thorough assessment of the progress of sustainability, thus initiating strategic tourism development reforms.
\end{abstract}

Keywords: Tourism, Sustainability, Policy approach, Perception.

\section{INTRODUCTION}

Sustainable development as a concept firstly emerged with concerns related to protection of natural environment [41, 43], and later expanded to socio-economic issues [39, 42]. As such, the concept reflected in a "triple pillar" context understood as a principle to meet human development goals and to sustain natural systems to supply the natural resources while achieving social, environmental, and economic progress [23, 47].

With regards to tourism sustainability, it is a concept vastly debated, but with a consensus that understanding the principles of sustainability is the most essential for sustaining tourism development $[18,31,33]$. So, it encompasses socio-cultural, environmental, and economic tourism impacts as three theoretical pillars. Due to numerous impacts tourism has on destinations, it is important to understanding stakeholders' perception (local communities, tourists, operators, and regulators). By understanding tourism sustainability from different perspectives may assist in minimizing the negative and maximizing the positive tourism effects. Only if all tourism segments unify and work together, sustainability may be achieved [19, 44]. 
There has been a long debate on tourism sustainability with various discussion on different aspects. Regardless the interpretations, it is concluded that sustainability means a concept that incorporates social, ecological, and economic aspects, with a main concern on their optimization. In this line, United Nations' Agenda 2030 foresees meeting 17 sustainable development goals [38] and understanding principles of sustainability $[18,32$, 33].

Some aspects of sustainability have been elaborated long time ago, like the tourism demand aspect as a one-site measurement in terms of controlling sustainability [8, 24], the macro and micro approaches when addressing sustainability of tourism resources [15], even the issues of the inter-generational in favor of intra-generational equity as an essential prerequisite of sustainable tourism $[5,45]$.

Furthermore, various concepts are argued, and numerous theories are utilized, from the mostly employed Social exchange theory [1], Tourist area life cycle [7], and Irridex model [12], to the new ones, like: Stakeholders theory, which has been extensively debated [9, 10, 16, 25, 46], Dependency theory [20], Place attachment theory [17], Resistance theory [11], and many more [27]. Additionally, many studies include policy enablers' perception $[13,30,32,34]$. On the other hand, there are negative examples where investments have not sustained and gained sustainability [39, 40].

The paper follows previous findings of the mainstream sustainability pillars to identify tourism impacts, by assessing tourism destinations' operating sustainability from a policy perspective. In this line, the policymakers are those who manage and control tourism destination's development, as tourist organizations, governmental agencies, management bodies, etc. A model is suggested as a framework for strategic tourism development reforms, and it is applied on the case of Serbia. The model posts directions for policymakers to assess the current state of well-being of tourism destinations as well as to direct and monitor policies towards sustainable development.

After the introduction, some stylized facts on Serbia as a study area are presented. The next section presents the applied methodology, followed by discussion and conclusion. The study contributes to the literature review on tourism sustainability in Serbia as already previously discussed [30].

\section{STUDY AREA}

The research is applied on Serbia (Figure 1) as a country that practices tourism despite many limitations for prosperous development, as lack of finances and limited investments in tourism, low GDP, etc. Some studies have applied the stakeholders' theory on tourism in Serbia [2, 13], but this research adds by quantifying Serbia's operating sustainability of tourism destination.

Although Serbia has recognized tourism as a priority developmental area with very important task towards the European Union integration [28], there is a shortage of precise priority actions needed to make it more sustainable [22]. The National Tourism Organization is responsible for tourism promotion at the national level and three regional tourism organizations (Vojvodina, West Serbia and Sandžak) at regional level. Furthermore, there are over 130 local tourism organizations at municipal level, over 300 tourist agencies, about 200 hotels and restaurants, and almost 200 licensed tour guides [30]. 


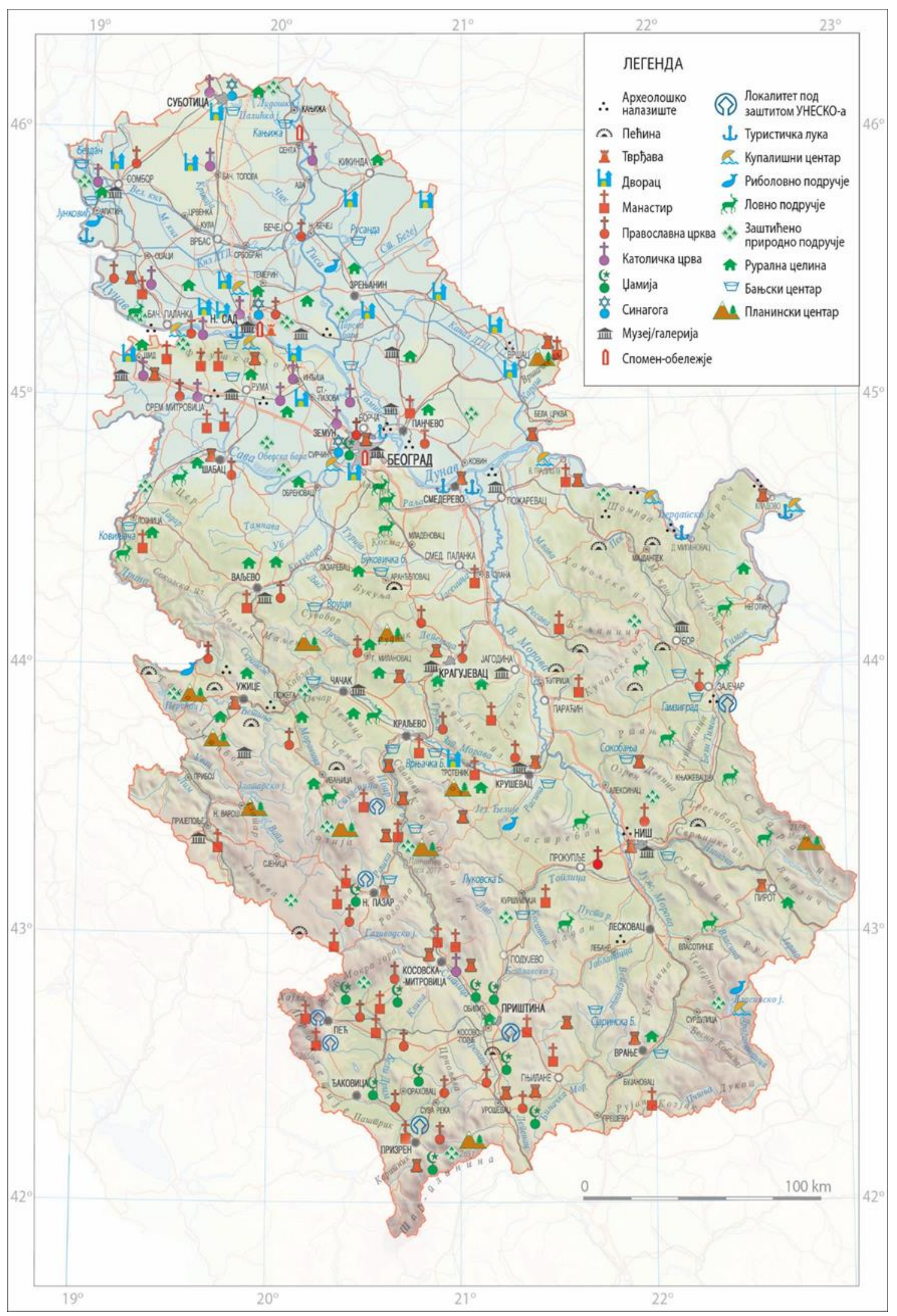

Figure 1. Tourism map of Serbia

Source: [4], author: Milovan Milivojević 
The overall sustainability framework is defined within the National Strategy on Sustainable Development [28] and the Strategy of Tourism Development 2016-2025 [29]. Although the concept foresees a balance between the main sustainability pillars (sociocultural, environmental, and economic), yet, the accent is on issues related to the proper use of natural resources. Additionally, many regional plans, tourism destination master plans, municipal development plans and so forth, further address development of tourism destinations in Serbia. Despite the presence of many documents related to the issue of sustainability, a profound lack of inter-sectoral coordination is noted [22] and a dialog to develop commonly desirable policies $[6,36]$.

\section{METHODOLOGY}

The study applies a multi-stage methodology to understand policy enablers' perception on the operating sustainability of tourism destinations in Serbia.

In the first stage, a qualitative method was applied, when data was collected by expert's judgment and content analysis of the existing strategic tourism development documents [35]. The goal was to identify if the core sustainability issues were properly addressed by the policymakers, and the frequency referenced by the interviewees from the second stage. The main secondary sources were the National Strategy on Sustainable Development [28], the Strategy of Tourism Development [29], regional development plans, tourism destinations' master plans, and municipal tourism development plans.

In the second stage, a quantitative method was applied. Moreover, 219 half-structured deep interviews were conducted during the International Belgrade Tourism Fair in February 2018. Very often, fairs are used in research as gathering point with high frequency $[3,21]$. The respondents came from 79 municipalities, covering about $60 \%$ of all local tourism organizations in Serbia.

Table 1. Summarized structure of the interview protocol

\begin{tabular}{|l|l|}
\hline Section & Aim \\
\hline Introduction & Explaining the research aim. \\
\hline Perception & $\begin{array}{l}\text { Gathering data (full notes) on 12 sustainable indicators to assess } \\
\text { policy enablers'perception on socio-cultural, environmental and } \\
\text { economic impacts }\end{array}$ \\
\hline $\begin{array}{l}\text { Enablers' policy and } \\
\text { challenges }\end{array}$ & $\begin{array}{l}\text { Gathering data (full notes) on necessity of reform of tourism } \\
\text { development in the destination }\end{array}$ \\
\hline Interviewee data* & $\begin{array}{l}\text { Gathering demographic and socio-economic data, as well as data } \\
\text { on policy level and type of organization }\end{array}$ \\
\hline
\end{tabular}

Note:

*The sample consisted of:

- Tourism policy organizations: local $79 \%$, regional $8.4 \%$, national $10.9 \%$, and international $1.7 \%$. -

- Working position: managers $35.3 \%$, and employees $64.7 \%$.

- Type of organization: public $85.6 \%$, and private $14.4 \%$.

- Working at: research centers and universities $4.2 \%$, municipal institutions such as tourist organizations and offices $66.4 \%$, hotels and other establishments $15.1 \%$, and cultural and other associations $14.3 \%$.

- Gender: male $35.6 \%$, and female $64.4 \%$.

- Age: between 36-60 years old 49.2\%, 18-45 years $46.6 \%$, and older than 60 years $4.2 \%$.

- Education: university $87.3 \%$, and $12.7 \%$ high school.

Besides the three main researchers, additional six students were engaged, forming three groups (a senior and two students) holding an interview between 15-20 min. in the local language. To avoid overlapping of respondents, each group marked the interviewees on a spread-shit and exchange it among each other. The interviews were guided by an 
interview protocol, consisting of open-ended questions allowing free discussion with minimum intervention (Table 1). Full notes were taken for a qualitative evaluation on a broad spectrum of policy issues to determine respondents' perspectives on reform challenges of current tourism development. Additionally, respondents were asked to add if any omitted, but relevant aspect of tourism policy reform. Based on the expert's judgment, findings are summarized, and conclusion is done. Beside qualitative perception, respondents gave quantitative evaluation on the three sustainability pillars on the five-point Likert Scale.

Based on the exploratory factor analysis, a structural equation modelling was performed. It presents the relationship between the factors on tourism sustainability impacts in Serbian tourism destinations.

\section{RESULTS}

Upon the rate of respondents' level of agreement with sustainability indicators, critical factors affecting operating sustainability of tourism destinations in Serbia are identified (Table 2). The factor analysis is appropriate since the overall Cronbach's alpha (0.83) is much above the suggested limit of 0.6 [26], the Kaiser-Meyer-Olkin value (0.634) is a mediocre [14], and the Bartlett's test $(\mathrm{p}<0.05)$ is significant.

Table 2. Tourism sustainability factors of tourism destinations in Serbia.

\begin{tabular}{|l|l|l|l|}
\hline No & Factor & Item & Loading \\
\hline 1 & $\begin{array}{l}\text { Socio-cultural } \\
\text { environment }\end{array}$ & $\begin{array}{l}\text { - Social equity } \\
- \text { Authenticity of the destination } \\
- \text { Cultural richness }\end{array}$ & 0.744 \\
\hline 2 & Services & $\begin{array}{l}\text { - Transport services } \\
- \text { Communal services }\end{array}$ & 0.807 \\
\hline 3 & $\begin{array}{l}\text { Environmental } \\
\text { impacts }\end{array}$ & $\begin{array}{l}\text { - Natural resources } \\
- \text { Local community involvement in } \\
\text { environmental protection }\end{array}$ & 0.882 \\
\hline 5 & Economic impacts & $\begin{array}{l}\text { - Economic viability } \\
- \text { Employment quality } \\
\text { - Local prosperity }\end{array}$ & 0.832 \\
\hline $\begin{array}{l}\text { Policy enablers } \\
\text { destination }\end{array}$ & $\begin{array}{l}\text { - Managing sustainability of tourist } \\
\text { destination }\end{array}$ & 0.900 \\
\hline
\end{tabular}

Note: Extraction method: principal axis factoring. Rotation method: promax with Kaiser normalization

The relationships between the factors of Table 2 are presented in Figure 2. The model has a good fit, since the $\chi^{2}(111.2)$ is significant, $\chi 2 / \mathrm{df}(2.47)$ has a value lower than 5 , the CFI (0.929) and the IFI (0.931) are above 0.9, the RMSEA (0.063) is slightly over 0.05 , and the SRMR (0.552) is well below 0.8. As such, all fit indices are above the cut-points. The model enables direct links with other factors towards policy enablers. Yet, some issues need additional clarification since some relations in the Figure 1 may be easily misinterpreted. It is noticeable that the largest impact has the factor services (transport and communal). It is very likely to expect positive economic effects of transport and communal services, which is not the case.

Herein, the negative correlation is explained by respondents' distribution where substantial number express neutral perceptions on employment quality assessment, visà-vis the largest number of negative impressions concerning the local prosperity issues. This is completely understandable, since as the negative perception on environmental 
impact grows, the bigger is the influence on the policy enablers to create development policy for preserving and protecting the environment from tourism impacts. The same is the issue with the correlations related to the policy enablers. Namely, there are mostly neutral statements on monitoring and managing sustainability levels, and $38.3 \%$ and $38.9 \%$ of negative assessment when evaluating monitoring process and the management aspect of sustainability at destinations, respectively. The lowest is the influence of the independent variable socio-cultural environment, even though for foreign tourists, culture development and cultural events are often the most important motives for visiting tourism destination

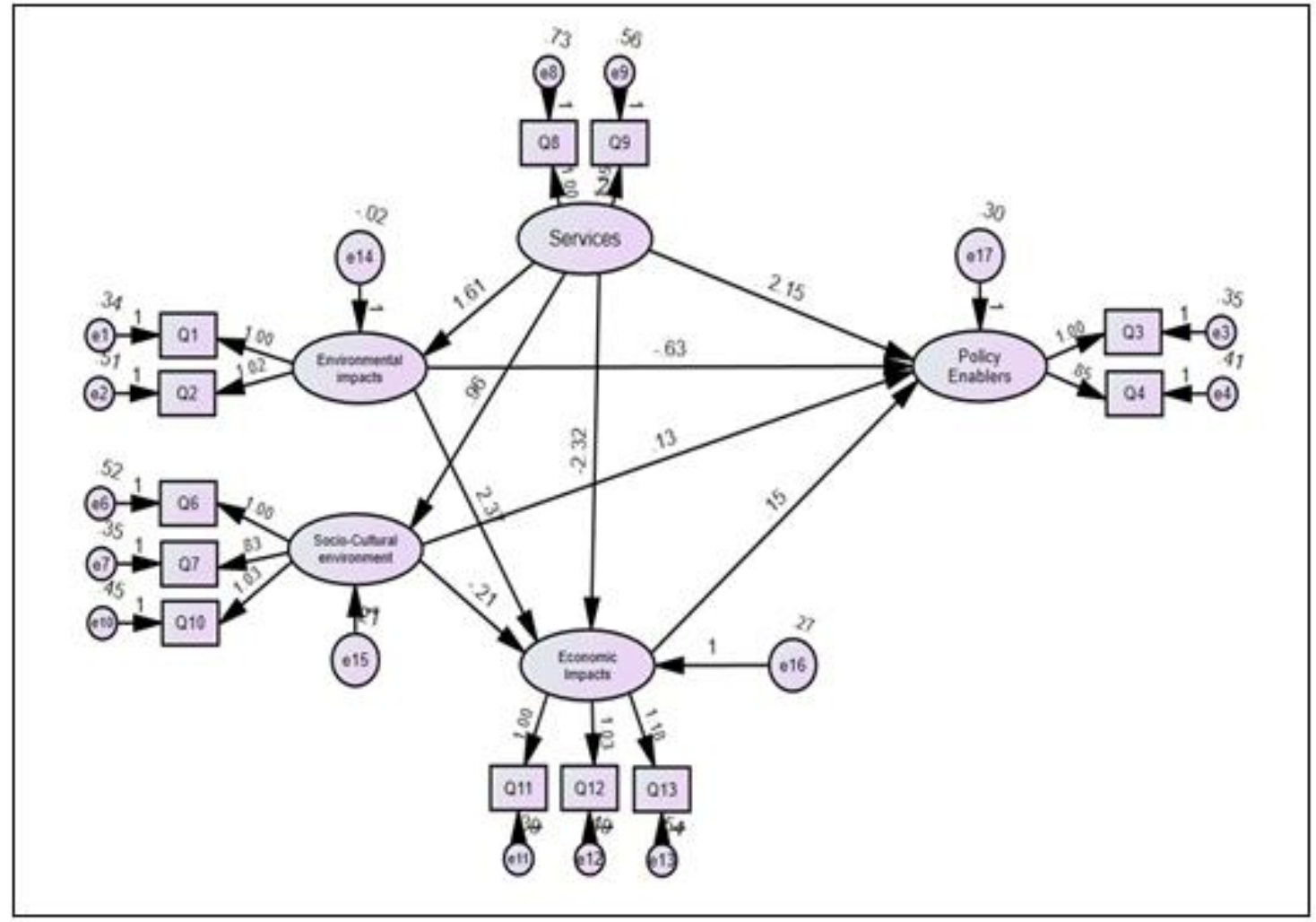

Figure 2. Structural equation model

Source: Authors

\section{DISCUSSION}

Based on collected qualitative data and the content analysis of current strategic tourism development documents, along with the expert's judgment, the research found convergences and divergences with respondents' perception. As similarity, it was found the same general perception that tourism in Serbia offers numerous benefits for tourism destinations and consequently should be positively acknowledged. Similarity was also found in the expressions of distress when monitoring tourism product quality.

On the other hand, differences were also noted. The study found that tourism development documents address the broad concerns with no care to achieve sustainability. As such they lack enhancing the local opportunities for the future, which is substantial element of sustainability. This is the main concern of interviewed policymakers.

Furthermore, when assessing tourism factors that affect operating sustainability of Serbian tourism destinations, the study found that the socio-cultural impacts are perceived as the most beneficial by the policy enablers. More precisely, authenticity and uniqueness 
of destination are the most relevant for sustainable development. As such, Serbia should be focused on the cultural values which are found to mediate environmental and economic perceptions at a destination level.

Strangely, but the environmental factor was identified with a medium impact. So, the ecological setting in terms of physical integrity, diversity, resource efficiency and the environmental purity, was found to be very sensitive. According to policy enablers, this provokes a need to raise the environmental issue at a higher developmental level to be properly addressed.

Even though economic sustainability in terms of employment, viability and local prosperity is important for tourism destinations, for Serbia, is in the phase of supporting development of infrastructure, product design, and marketing. So, the core concept of wellbeing is missing.

Additionally, the study found that policy makers are seriously concerned with the process of planning sustainable tourism development and urge the need for re-shaping the current strategic tourism documents. An accent is put on responsible controlling and a lack of coordination at all levels of policymaking, particularly in terms of consolidation of different development goals and tourism plans. With no cooperative attitude and marginalized role of the local community, sustainability in tourism development is missed. As such, the main sustainability aspects (socio-cultural, environmental, and economic) despite being extremely relevant for tourism destinations' development, are not operating at optimum level.

\section{CONCLUSION}

The study investigated policymakers' perception on the main tourism challenges and shortcomings when addressing the issue of sustainability of Serbian tourism destinations. A model is proposed that posts directions for systematic organization of policymakers to infer conclusions on the current state of well-being of tourism destinations. Such model enables thorough assessment of the progress of sustainability, thus initiating strategic tourism development reforms. The research revealed that policymakers are focused on maintaining several elements of the environmental quality of tourism destinations (as authenticity and ambient), which might be effective only on short-term, unlike sustainability which is a long-term concept. There is a need to re-shift the perception from just ecological concern into much complex issue with a three-dimensional concern. The way out in enhancing current modest tourism sustainable development is detected in reshaping the strategies into effective ones along with improvements and solid changes in the policy context for embracing the sustainability. At the standing point, tourism destinations in Serbia are rather managed in a maintainable than in a sustainable manner

\section{REFERENCES}

[1] Ap, J. Residents' perceptions in tourism impacts, Annals of Tourism Research, vol. 19, pp 665-690, 1992.

[2] Armenski, T., Dwyer, L., \& Pavluković, V. Destination competitiveness: Public and private sector tourism management in Serbia, Journal of Travel Research, vol. 57, pp 384-398, 2018.

[3] Berne, C., \& Garcia-Uceda, M. Targeting efficiencies among trade show nonattendees, Journal of Targeting, Measurement and Analysis of Marketing, vol. 15, issue 3, pp 146-157, 2007. 
[4] Bjeljac, Ž., Terzić, A., Jovanović, A., Brankov, J., \& Petrović, M. Tourism of Serbia (in Serbian). In: Geography of Serbia; Milan Radovanović (Ed.), Special issue of Geografical Institute "Jovan Cvijić", SASA, 91, 2017, pp 753-809.

[5] Bramwell, B. Selecting policy instruments for sustainable tourism. In: Global Tourism; William F. Theobald (Ed.), Butterworth Heinemann: Oxford, UK, 1998, pp. 361-379.

[6] Bramwell, B., \& Lane, B. Tourism Collaboration and Partnerships: Politics, Practice and Sustainability, Channel View Publications: Clevedon, UK, 2000.

[7] Butler, R.W. The concept of a tourist area life cycle of evolution: Implications for management of resources, Canadian Geographer, vol. 24, issue 1, pp 5-12, 1980.

[8] Butler, R.W. Sustainable tourism: A state-of-the art review, Tourism Geography, vol. 1, pp 725, 1999.

[9] Byrd, E.T. Stakeholders in sustainable tourism development and their roles: Applying stakeholder theory to sustainable tourism development, Tourism Review, vol. 62, pp 6-13, 2007.

[10] Byrd, E. T., Bosley, H. E., \& Dronberger, M. G. Comparisons of stakeholder perceptions of tourism impacts in rural eastern North Carolina, Tourism Management, vol. 30, pp 693-703, 2009.

[11] Chhabra, D. How they see us: Perceived effects of tourist gaze on the old order Amish, Journal of Travel Research, vol. 49, pp 93-105, 2010.

[12] Doxey, G. V. A causation theory of visitor-residents irritants, methodology and research inferences, 6th annual conference proceedings of the Travel Research Association, San Diego, CA, pp 195-198, 1975.

[13] Dwyer, L., Dragićević, V., Armenski, T., Mihalič, T., \& Knežević Cvelbar, L. Achieving destination competitiveness: An importance-Performance analysis of Serbia, Current Issues of Tourism, vol. 19, pp 1309-1336, 2016.

[14] Field, A. Discovering Statistics Using SPSS, 3rd ed., SAGE Publications Inc.: London, UK, 2009.

[15] Garrod, B., \& Fyall, A. Beyond the rhetoric of sustainable tourism, Tourism Management, vol. 19, pp 199-212, 1998.

[16] Garrod, B., Fyall, A., Leask, A., \& Reid, E. Engaging residents as stakeholders of the visitor attraction, Tourism Management, vol. 33, pp 1159-1173, 2012.

[17] Gu, H., \& Ryan, C. Place attachment, identity and community impacts of tourism: The case of a Beijing hutong, Tourism Management, vol. 29, pp 637-647, 2008.

[18] Harrill, R. Residents' attitudes toward tourism development: A literature review with implications for tourism planning, Journal of Planning Literature, vol. 18, issue 3, pp 251-266, 2004.

[19] Ko, T. Development of a tourism sustainability assessment procedure: A conceptual approach, Tourism Management, vol. 26, pp 431-445, 2005.

[20] Lepp, A. Tourism and dependency: An analysis of Bigodi Village, Uganda, Tourism Management, vol. 29, pp 1206-1214, 2008.

[21] Li, L. Y. Marketing resources and performance of exhibitor firms in trade shows: A contingent resource perspective, Industrial Marketing Management, vol. 36, issue 3, pp 360-370, 2007.

[22] Maksin, M., \& Milijić, S. Strategic planning for sustainable spatial, landscape and tourism development in Serbia, Spatium, vol. 23, pp 30-37, 2010.

[23] Mensah, J., \& Ricart Casadevall, S. Sustainable development: Meaning, history, principles, pillars, and implications for human action: Literature review, Cogent Social Sciences, vol. 5, issue 2, pp 1653531, 2019. 
[24] Middleton, V. T. C.; Hawkins, R. Sustainable Tourism: A Marketing Perspective, Butterworth-Heinemann: Oxford, UK, 1998.

[25] Nicholas, L. N., Thapa, B., \& Ko, Y. J. Residents' perspective of a world heritage site: The Pitons Management Area, St. Lucia, Annals of Tourism Research, vol. 36, pp 390-412, 2009.

[26] Nunnally, J., \& Bernstein, I.H. Psychometric Theory, 3rd ed.; McGraw-Hill: New York, NY, USA, 1994.

[27] Nunkoo, R., Smith, S.L., \& Ramkissoon, H. Residents' attitudes to tourism: A longitudinal study of 140 articles from 1984 to 2010, Journal of Sustainable Tourism, vol. 21, issue 1, pp 5$25,2013$.

[28] Official Gazette of the Republic of Serbia, 57/2008. National Strategy of Sustainable Development: Belgrade, Serbia, 2008.

[29] Official Gazette of the Republic of Serbia, 98/2016. Strategy of Tourism Development 20162025, Belgrade, Serbia, 2016.

[30] Petrevska, B., Terzić, A., \& Andreeski, C. More or less sustainable? Assessment from a policy perspective, Sustainability, vol. 12, issue 8, pp 3491, 2020.

[31] Popescu, G. H., Sima, V., Nica, E., \& Gheorghe, I. G. Measuring sustainable competitiveness in contemporary economies - Insights from European economy, Sustainability, vol. 9, pp 12-30, 2017.

[32] Ramdas, M., \& Mohamed, B. Visitor perceptions on the impacts of tourism activities, development and infrastructure on the environment of Perhentian Islands, SHS Web of Conferences, vol. 12, 2014, pp 10-81.

[33] Sharpley, R. Host perceptions of tourism: A review of the research, Tourism Management, vol. 42, pp 37-49, 2014.

[34] Shen, F., \& Cottrell, S. A sustainable tourism framework for monitoring residents' satisfaction with agritourism in Chongdugou Village, China, International Journal of Tourism Policy, 1-4, 2008.

[35] Stone, P. J., Dunphy, D. C., Smith, M. S., \& Ogilvie, D. M. The General Inquirer: A Computer Approach to Content Analysis, MIT Press: London, UK, 1966.

[36] Terzić, A. Pristup umrežavanja aktera kao neophodan faktor razvoja kulturnog turizma u Srbiji, Kultura, vol. 150, pp 254-270, 2016.

[37] Terzić, A., \& Bjeljac, Ž. Problemi revitalizacije arhitektonskog naslegja i turističkog uregjenja u Srbiji: Dvorac Šicer, Beočin, Kultura polisa, vol. 28, pp 475-488.

[38] Terzić, A., \& Denda, S. Efekti prekogranične saradnje na prostoru Srpskog Banat ana turistički razvoj regiona, Kultura polisa, vol. 38, pp 519-532, 2019.

[39] UN. World Summit on Sustainable Development Report, 2002. Available online: https://www.un.org/ga/search/view_doc.asp?symbol=A/CONF.199/20/Corr.1\&Lang=E (accessed on 25 March 2020).

[40] UN. Transforming Our World: The 2030 Agenda for Sustainable Development, A/RES/70/1, 2015. Available online:https://sustainabledevelopment.un.org/content/ documents/21252030\%20Agenda\%20for\%20Sustainable\%20Development\%20web.pdf (accessed on 25 March 2020).

[41] UNCED - United Nations Conference on Environment and Development. Agenda 21, 1992. Available online: www.ciesin.org/TG/P1/TREATY/unced.html (accessed on 25 March 2020).

[42] UNCED-United Nations Conference of Sustainable Development, Rio +20, 2012. Available online: https://sustainabledevelopment.un.org/rio20/futurewewant (accessed on 25 March 2020).

[43] UNEP. World Charter for Nature; UNEP: Nairobi, Kenya, 1982. 
[44] Viljoen, F. Sustainability Indicators for Monitoring Tourism Route Development in Africa. Ph.D. Thesis, University of Stellenbosch, Stellenbosch, South Africa, 2007.

[45] Wahab, S., \& Pigram, J. J. Tourism and sustainability: Policy considerations. In: Tourism, Development and Growth. The Challenge of Sustainability; Wahab, S., Pigram, J.J., Eds.; Routledge: London, UK, 1998; pp. 277-290.

[46] Yu, C. P., Chancellor, H. C., \& Cole, S. T. Measuring residents' attitudes toward sustainable tourism: A reexamination of the sustainable tourism attitude scale, Journal of Travel Research, vol. 50, pp 57-63, 2011.

[47] Zhai, T. T., \& Chang, Y.C. Standing of environmental public-interest litigants in China: Evolution, obstacles and solutions, Journal of Environmental Law, vol. 30, pp 369-397, 2019. 